DOI: https://doi.org/10.31933/dijms.v3i1 Received: 12 August 2021, Revised: 25 August 2021, Publish: 28 September 2021

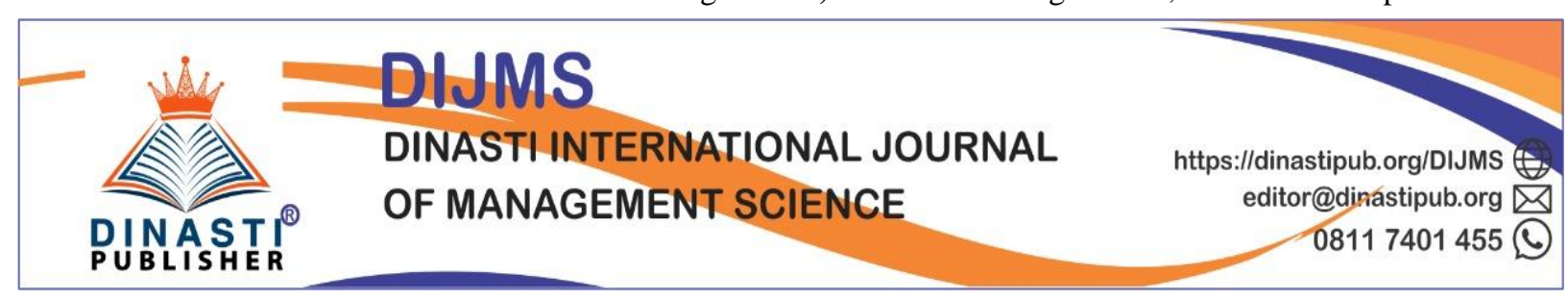

\title{
THE INFLUENCE OF LEADERSHIP AND ORGANIZATIONAL COMMITMENT ON EMPLOYEE PERFORMANCE THROUGH WORKING DISCIPLINES AS INTERVENING VARIABLES
}

\author{
Fachrudi Fachrudi ${ }^{1}$, Parwoto Parwoto ${ }^{2}$, Ahmad Badawi Saluy ${ }^{3}$ \\ 1) Mercu Buana University, Jakarta, Indonesia, fachrudi.fahim@gmail.com \\ 2) Mercu Buana University, Jakarta, Indonesia, parwoto.parwoto@mercubuana.ac.id \\ ${ }^{3)}$ Mercu Buana University, Jakarta, Indonesia, ahmad.badawi@mercubuana.ac.id
}

\section{Corresponding Author: Fachrudi}

\begin{abstract}
The purpose of this study was to determine and analyze the influence of leadership and organizational commitment on work discipline as well as the influence of leadership, organizational commitment and work discipline on employee performance. This study uses primary data obtained from distributing questionnaires containing respondents' opinions about employee performance from the perspective of leadership, organizational commitment, and work discipline in one of the routes handled by the company. The sampling method used was convenience sampling. Of the population of 50 taken, all of them become the sample of this study. The analytical method used is SEM PLS using SmartPLS 3.2 software. The results of this study indicate that leadership has no effect on work discipline and employee performance, nor does it have an indirect effect on employee performance through work discipline. Meanwhile, organizational commitment has a significant positive effect on work discipline and employee performance, and has an indirect effect on employee performance which is partially mediated by work discipline. Likewise, work discipline has a significant positive effect on employee performance.
\end{abstract}

Keywords: Leadership, Organizational Commitment, Work Discipline, Employee Performance

\section{INTRODUCTION}

PT ALS is a company that offers transportation services for the collection and delivery of vehicle parts. PT ALS provides an interplant delivery system that involves moving goods from one customer's factory to another branch of the factory. In addition, PT ALS also serves the milkrun system, which is a method of delivery to several partner dealers and suppliers in one trip, so that partners can receive stock as quickly as possible.

Based on the results of the pre-research survey, the following conditions were found:

a. From a leadership aspect, $60 \%$ of leaders do not praise the performance of their subordinates, $70 \%$ of leaders give less encouragement to their subordinates, $70 \%$ of leaders are less involved in activities with their subordinates. 
b. From the aspect of organizational commitment, $60 \%$ of employees do not have the desire to stay behind from the benefits, $60 \%$ of employees feel they have no responsibility if they leave the company, $70 \%$ of employees are less aware of the commitment that must be made.

c. From the aspect of work discipline, that $70 \%$ of employees are less responsible for the assigned tasks, $70 \%$ of employees do not do the appropriate work, $70 \%$ of employees do not always comply with the hours of work.

The aforementioned condition is a problem as well as a challenge for PT ALS to be able to progress even better, so that handling must be done immediately so that employee performance can increase and company goals can be achieved.

\section{Identification of Problems}

Based on the research background that has been presented above, the following problems were identified:

1. Lack of attention from superiors to the performance of their subordinates.

2. Lack of encouragement from superiors to subordinates in completing their duties.

3. Lack of involvement of superiors in activities with their subordinates.

4. Lack of employee desire to stay because of the benefits.

5. Lack of employee care if they have to leave the company.

6. Lack of employee awareness of the commitment that must be done.

7. Lack of employee responsibility for the assigned task.

8. Lack of suitability for the work performed by employees.

9. Lack of employee obedience to hours of entry and return from work.

10. Lack of employee performance in carrying out their duties and work targets set by the company.

\section{Formulation of the Problem}

Based on the description of the problem, the problem formulations to be reviewed are:

1. Does leadership affect the work discipline of PT ALS employees?

2. Does commitment affect the work discipline of PT ALS employees?

3. Does leadership affect the performance of PT ALS employees?

4. Does commitment affect the performance of PT ALS employees?

5. Does work discipline affect the performance of PT ALS employees?

6. Does leadership have an indirect effect on employee performance through work discipline of PT ALS employees?

7. Does organizational commitment have an indirect effect on performance through work discipline of PT ALS employees?

\section{Research Objectives}

From the formulation of the problem above, the objectives of this study are to:

1. To determine the influence of leadership on the work discipline of PT ALS employees.

2. To determine the effect of organizational commitment on the work discipline of PT ALS employees. 
3. To determine the influence of leadership on the performance of PT ALS employees.

4. To determine the effect of organizational commitment on the performance of PT ALS employees.

5. To determine the effect of work discipline on the performance of PT ALS employees.

6. To determine the indirect effect of leadership on the performance of PT ALS employees through work discipline.

7. To determine the indirect effect of organizational commitment on the performance of PT ALS employees through work discipline.

\section{LITERATURE REVIEW}

\section{Employee Performance}

An organization is formed to achieve common goals, but to achieve goals effectively requires good and correct management. "Management is a process of using organizational resources to achieve organizational goals through the functions of planning and decision making, organizing, leading, and controlling”.

A design that is focused on organizational goals in achieving maximum organizational performance. Performance is often defined as performance, work results, or work performance. Performance has a broader meaning, not only as a result of work, but how the work process takes place. An organization can progress and develop or vice versa depending on the performance of the organization which is supported by the personal performance of the organization. Suwarno and Priansa (2011) state that "performance is the result of a process carried out by humans".

Robert Becal (2007) explains that "performance management is a continuous communication process, carried out in the context of cooperation between an employee and his direct supervisor, which involves setting expectations. Performance management is a complete tool used with the aim of optimizing the success of every employee, work group, manager, and organization. Performance management is a great way to take advantage of employees' knowledge, skills and experience".

On the other hand, the term performance is often associated with the term productivity, many people claim that in fact productivity is a specific concept related to the ratio between output and input performance, is a term that involves almost all the objectives of competition and manufacturing advantages such as cost, flexibility, speed, dependability, and quality. But those performance objectives can have a greater impact on productivity in operations.

\section{Discipline}

Etymologically, discipline comes from the Latin word disipel which means follower, but along with the times, the word has changed to disipline which means obedience or which involves discipline. Work discipline according to Sutrisno (2010) is "an attitude of a person's willingness and willingness to comply with and obey the prevailing regulatory norms".

According to Hasibuan (2012), "discipline is the awareness and willingness of a person to obey all rules and norms that apply and are enforced in a company. Without the support of 
good discipline, it is difficult for companies to realize their goals. So discipline is the key to company success".

"Discipline is the sixth operative function of Human Resource Management. The better the employee discipline, the higher the work performance that can be achieved. Without good discipline, it is difficult for organizations to achieve maximum results. Work discipline is a tool used by managers to communicate with employees so that they are willing to change a behavior as well as an effort to increase awareness and availability of a person to comply with all company regulations and prevailing social norms" (Rivai, 2013).

\section{Organizational Commitment}

According to Robbins (2006), "employee commitment to an organization is a condition in which employees take sides with the organization and its goals, and intend to maintain their membership in that organization. Organizational commitment consists of likes or interests (attachments) of employees to the organization where the employee works" (Laschinger, 2001). Mathis and Jackson (2002) argue that "Organizational commitment is the level of trust and acceptance of labor towards organizational goals and a desire to remain in the organization". Luthans (2002) defines "organizational commitment as an attitude that shows employee loyalty and is an ongoing process of how an organization member expresses concern for the success and goodness of the organization". Robbins, (2006) argues that "high organizational commitment means that there is a high level of organizational support. Commitment as a predictor of one's performance is a better predictor of global nature, and persists in the organization as a whole rather than job satisfaction alone. A person can be dissatisfied with a particular job and think of it as a temporary condition, but dissatisfaction with the organization as a whole, and that dissatisfaction with the organization can encourage a person to consider resigning”.

\section{Leadership}

"Leaders are people who can influence others and have managerial authority. Leadership is what leaders do" (Robbins, \& Coulter, 2010). "Leadership is the process of leading a group and influencing the group to achieve its goals".

Robbins (2006) states that "leadership is the ability to influence groups towards achieving goals". Kouzes \& Posner (2004) state "leadership creates ways for people to contribute in creating something extraordinary". Boone \& Kurtz (1984) suggest that "leadership is an act of motivating other people or causing others to do certain tasks with the aim of achieving certain goals". Meanwhile, Tzu \& Cleary (2002) argue that "leadership is a matter of intelligence, trust, gentleness, courage, and assertiveness". 


\section{Framework}

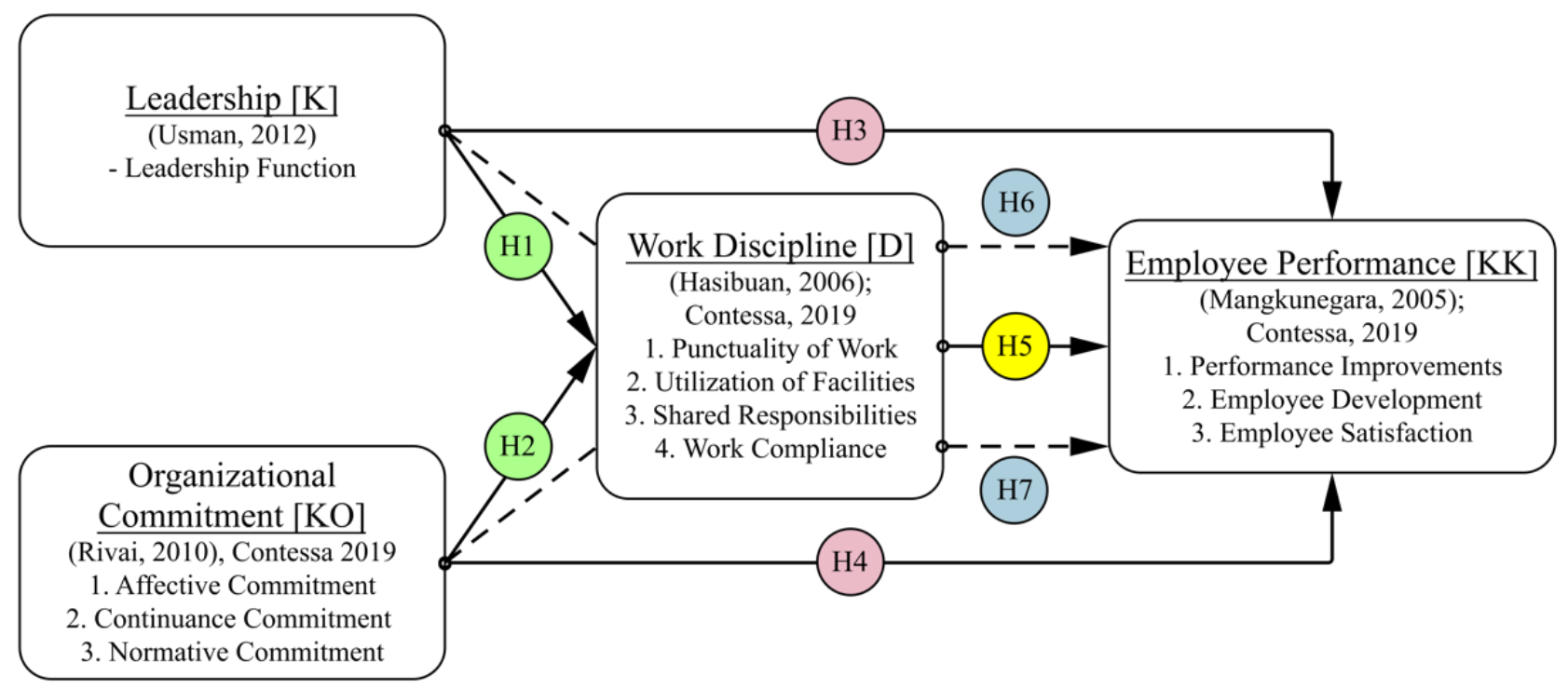

Figure 1. Framework

\section{RESEARCH METHODS Type of Research}

"Research methods are methods and procedures for obtaining data used for verification, discovery, development based on scientific principles" (Masyhudzulhak, 2015). "The research method can be interpreted as a scientific way to obtain valid data with the aim of being able to find, develop and prove certain knowledge so that in turn it can be used to understand, solve and anticipate problems" (Sugiyono, 2012). According to Sugiyono (2012), "in general the research method is defined as a scientific way to obtain data with specific purposes and uses. Researchers collect data from a population or sample, which has been determined and then described through data presentation".Types of research designs can be grouped based on objectives, approaches, level of explanation, analysis and types of data. In this study, the authors used a survey research method with quantitative descriptive statistics. According to Nana Syaodih, quoted by Bahrudin et.al (2015), "surveys are used to gather information in the form of opinions from a large number of people on certain topics or issues. There are three main characteristics of the survey":

1. "Information is collected from a large group of people to describe certain aspects or characteristics such as: abilities, attitudes, beliefs, knowledge of the population".

2. "Information is collected by asking questions (generally in writing although it can also be oral) from a population".

3. "Information is obtained from the sample, not from the population. The main purpose of the survey is to know the general description of the characteristics of the population".

"According to the type and data analysis, there are two research methods, namely qualitative and quantitative methods" This research will use quantitative methods. "Quantitative research methods can be interpreted as a research method based on the philosophy of positivism, used to examine specific populations or samples, sampling techniques are generally carried out randomly, data collection uses research instruments, data analysis is 
quantitative / statistical in order to test the hypothesis has been established". (Sugiyono, 2012). "In quantitative research, data analysis uses statistics, the data statistics used can be descriptive statistics" (Sugiyono, 2012).

\section{Research Variables}

The variables used in this study are as follows:

1. Independent Variables, According to Sugiyono (2013) are "variables that influence or cause changes or the emergence of the dependent variable (dependent). In SEM (Structural Equation Modeling), the independent variable is referred to as an exogenous variable". In this study, the independent variables are Leadership and Organizational Commitment.

2. Dependent Variable, According to Sugiyono (2013) "is a variable that is affected or that is the result, because of the independent variable. In SEM, the dependent variable is referred to as an endogenous variable. In this study the dependent variable is employee performance".

3. Intervening variables, according to Sugiyono (2013) "are variables that theoretically affect the relationship between independent and dependent variables into an indirect relationship and cannot be observed and measured. In this research, the intervening variable is work discipline".

\section{Data Collection Methods}

"Data collection methods are methods used to obtain data and information needed in research" (Sugiyono, 2017). The data collection methods used by the author in this study are:

1. Structured Interview.

2. Literature Research.

3. Internet Research.

\section{The Method Used}

The method used is divided into 2, namely:

\section{Descriptive Method}

"Descriptive analysis is providing or empirical descriptions of the data collected in the study" (Ferdinand in Ricardo 2012). The data comes from respondents' answers to the statements contained in the questionnaire and then obtained by the SmartPLS software.

\section{Inferential Statistical Methods}

"Inferential statistics are statistical techniques used to analyze sample data and the results are applied to the population" (Sugiyono in Kalnadi, 2013).

\section{Population}

According to Sugiyono (2010) "population is a generalization area consisting of objects / subjects that have certain qualities and characteristics that are determined by researchers to be studied and then draw conclusions". Meanwhile, according to Sukmadinata (2011), "the population is a large group and the area is the scope of the research". Therefore in every study, the population must be determined. Because from this population data will be obtained which 
will be processed and analyzed. In this study, the population was all corporate drivers, as many as 50 people.

\section{Sample}

According to Sugiyono (2010) "the sample is part of the number and characteristics of the population". Based on this understanding, researchers took samples using sampling and census techniques. The census is basically a survey research where the researcher takes all members of the population as respondents. The number of respondents taken as a sample is all divers on this route, namely 50 people.

\section{FINDING AND DISCUSSION}

\section{Respondent Characteristics}

Characteristics to be reviewed for respondents are based on age, gender, education and occupation. Respondents are employees and the questionnaire is distributed to 50 respondents.

\section{Outer Model Measurement \\ Convergent Validity}

Done to determine the correlation between variables with indicators, namely the variable leadership, organizational commitment, to employee performance through intervening variables (work discipline), then the analysis of the relationship between the indicators that make up the dimensions of these variables through path coefficient. And to find out the loading factor value, first input the value of each survey into the data in SmartPLS then create a path diagram according to the frame of mind with each variable being linked to its indicators. When finished then click Calculate and enter the "PLS Algorithma" option. The process produces a Full Structural_Awal Model (Algorithm) as shown below.

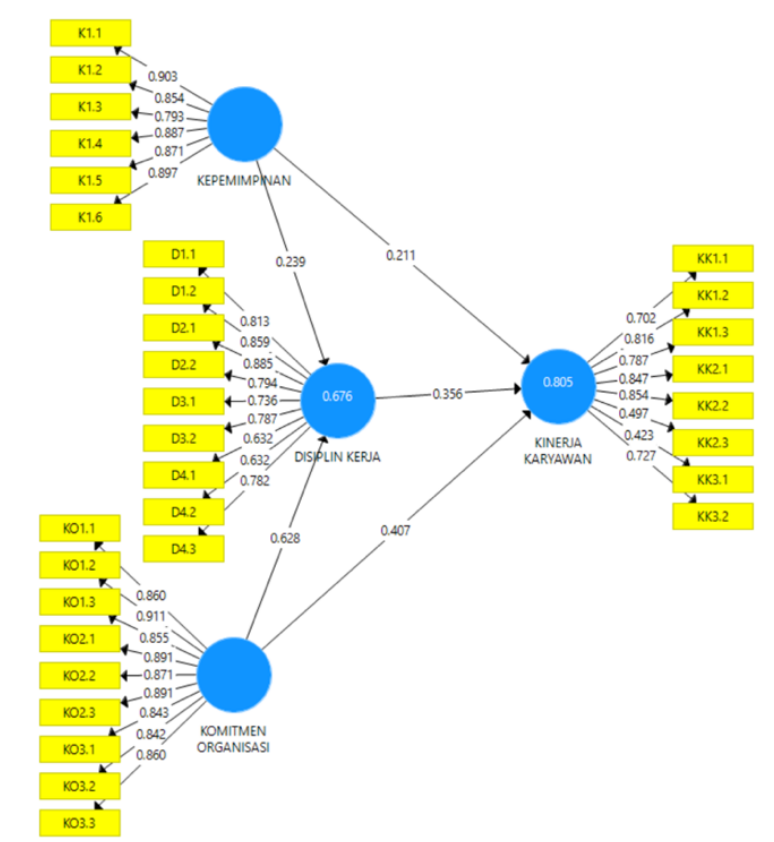

Figure 2. Full Structural Model_Initial (Algorithm) 
To be able to be tested at the next stage, namely the reliability test, invalid data must be deleted, then PLS Algorithm and Boostrapping are carried out again until all data (indicators) are valid, namely the loading factor value $>0.5$. To produce a valid value in the convergent validity test, the invalid indicators were removed 1 (one) time, namely D4.1, D4.2, KK2.3, and KK3.1.

The following is an image output of the structural model of the Calculate SmartPLS Algorithm result after the elimination of invalid indicators.

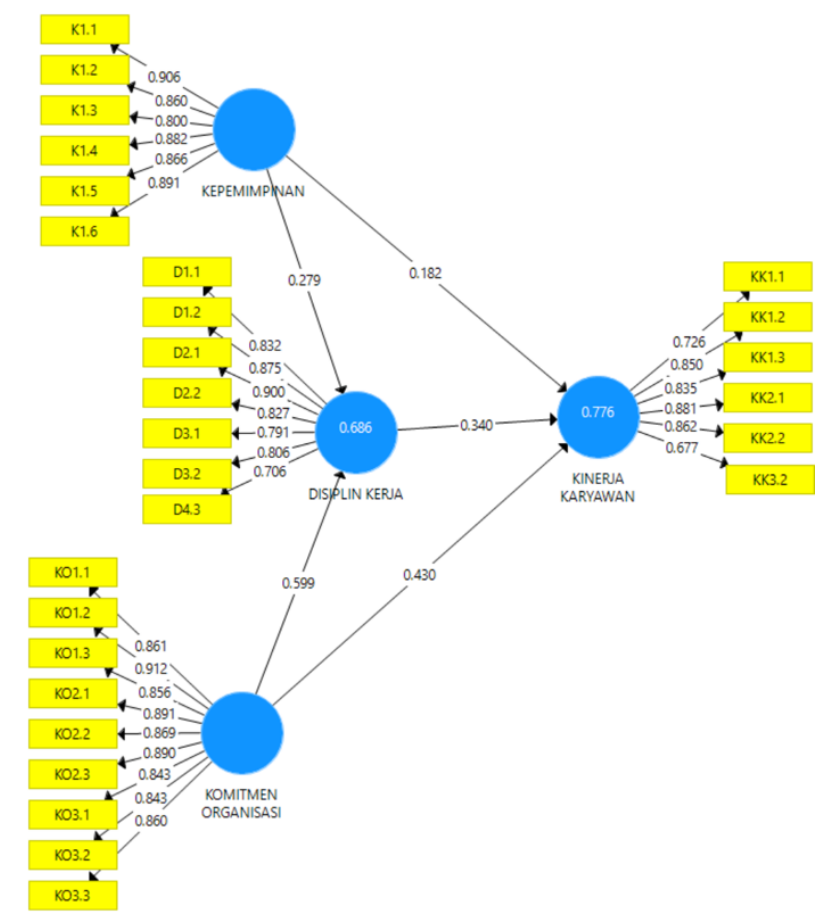

Figure 3. Full Structural Model_Fit (Algorithm)

It can be seen in the picture above that the loading factor value on all indicators is > 0.6. Whereas below is the output structure of the SmartPLS Bootstrapping result after the deletion of invalid indicators. 


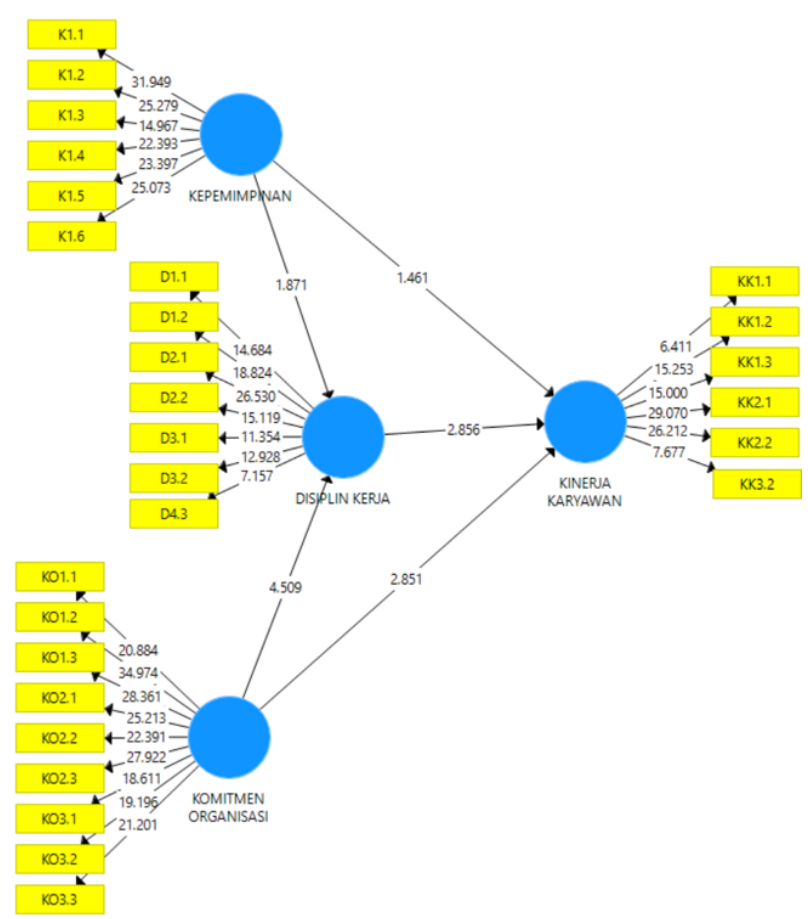

Figure 4. Full Structural Model_Fit (Bootstrapping)

Then, to facilitate the analysis of the loading factor data, it is exported to excel format, as shown in table 1.

Table 1. Cross Loading

\begin{tabular}{|c|c|c|c|c|}
\hline & WORK DISCIPLINE & LEADER-SHIP & EMPLOYEE PERFORMANCE & $\begin{array}{l}\text { ORGANIZATI-ONAL } \\
\text { COMMITMENT }\end{array}$ \\
\hline D1.1 & 0,832 & & & \\
\hline D1.2 & 0,875 & & & \\
\hline D2.1 & 0,900 & & & \\
\hline D2.2 & 0,827 & & & \\
\hline D3.1 & 0,791 & & & \\
\hline D3.2 & 0,806 & & & \\
\hline D4.3 & 0,706 & & & \\
\hline K1.1 & & 0,906 & & \\
\hline K1.2 & & 0,860 & & \\
\hline K1.3 & & 0,800 & & \\
\hline K1.4 & & 0,882 & & \\
\hline K1.5 & & 0,866 & & \\
\hline K1.6 & & 0,891 & & \\
\hline KK1.1 & & & 0,726 & \\
\hline KK1.2 & & & 0,850 & \\
\hline KK1.3 & & & 0,835 & \\
\hline KK2.1 & & & 0,881 & \\
\hline KK2.2 & & & 0,862 & \\
\hline KK3.2 & & & 0,677 & \\
\hline KO1.1 & & & & 0,861 \\
\hline KO1.2 & & & & 0,912 \\
\hline KO1.3 & & & & 0,856 \\
\hline KO2.1 & & & & 0,891 \\
\hline KO2.2 & & & & 0,869 \\
\hline KO2.3 & & & & 0,890 \\
\hline K03.1 & & & & 0,843 \\
\hline K03.2 & & & & 0,843 \\
\hline K03.3 & & & & 0,860 \\
\hline
\end{tabular}

Source: Output SmartPLS 
Table 1 above, shows the value of each indicator against the variable, so that the loading factor value in the 4 (four) variables of Leadership, Organizational Commitment, Work Discipline, and Employee Performance has all met the validity criteria, because it has a loading factor value. $>0.5$.

\section{Discriminant Validity}

Discriminant validity test can be done using the cross loading score in table 1.

The existence of good discriminant validity is indicated by the cross loading score which can be seen in table 1 above. Where the correlation score of the indicator to its construct is higher than the correlation score of the indicator with other constructs. For example, loading factor (LF) KO1.2 is 0.912 which is higher than LF with other variables such as KK3.2 with a variable of 0.677. And with other variables such as D2.1 of 0.900 , higher than LF with other variable indicators such as variable KK1.1 of 0.726 .

\section{AVE (Average Variance Extracted)}

The next method to test the validity of the data is to look at the Average Variance Extracted (AVE) value. The AVE value is said to be valid if it is $>0.5$.

The table below presents the SmartPLS output for AVE from the dimensions of Leadership, Organizational Commitment, Work Discipline, and Employee Performance.

Table 2. Average Variance Extracted (AVE)

\begin{tabular}{|l|c|c|c|c|}
\hline & $\begin{array}{c}\text { Cronbach's } \\
\text { Alpha }\end{array}$ & rho_A & $\begin{array}{c}\text { Average } \\
\text { Composite } \\
\text { Reliability }\end{array}$ & $\begin{array}{c}\text { Variance } \\
\text { Extracted } \\
\text { (AVE) }\end{array}$ \\
\hline WORK DISCIPLINE & $\mathbf{0 , 9 1 9}$ & $\mathbf{0 , 9 2 2}$ & $\mathbf{0 , 9 3 5}$ & $\mathbf{0 , 6 7 5}$ \\
\hline LEADERSHIP & $\mathbf{0 , 9 3 4}$ & $\mathbf{0 , 9 3 6}$ & $\mathbf{0 , 9 4 8}$ & $\mathbf{0 , 7 5 3}$ \\
\hline EMPLOYEE PERFORMANCE & $\mathbf{0 , 8 9 2}$ & $\mathbf{0 , 9 0 3}$ & $\mathbf{0 , 9 1 8}$ & $\mathbf{0 , 6 5 4}$ \\
\hline ORGANIZATIONAL COMMITMENT & $\mathbf{0 , 9 6 0}$ & $\mathbf{0 , 9 6 0}$ & $\mathbf{0 , 9 6 5}$ & $\mathbf{0 , 7 5 6}$ \\
\hline
\end{tabular}

AVE output as in table 2 above shows that 4 variables have a value above 0.50 so that they meet the discriminant validity requirements. (Wijayanto, 2008). X1 (Leadership) has an AVE score of $0.753, \mathrm{X} 2$ (Organizational Commitment) has an AVE value of 0.756, Y (Work Discipline) has an AVE score of 0.675, Z (Employee Performance) has an AVE score of 0.654. All variables have good convergent validity.

Table 3. AVE Value and AVE Root

\begin{tabular}{|l|c|c|}
\hline & $\begin{array}{c}\text { Average Variance } \\
\text { Extracted (AVE) }\end{array}$ & Root AVE \\
\hline WORK DISCIPLINE & $\mathbf{0 , 6 7 5}$ & $\mathbf{0 , 8 2 1}$ \\
\hline LEADERSHIP & 0,753 & 0,867 \\
\hline EMPLOYEE PERFORMANCE & $\mathbf{0 , 6 5 4}$ & $\mathbf{0 , 8 0 8}$ \\
\hline ORGANIZATIONAL COMMITMENT & $\mathbf{0 , 7 5 6}$ & $\mathbf{0 , 8 6 9}$ \\
\hline
\end{tabular}

Source: Output SmartPLS 
Table 3 above shows that the AVE Root score of the X1 variable (Leadership) is 0.867 higher than the AVE dimension correlation score, which is 0.753 , indicating the closeness of the dimensions. While the AVE Root value of the X2 variable (Organizational Commitment), which is 0.869 , is greater than the correlation value of the AVE dimension, which is 0.756 . The AVE root value of the $\mathrm{Y}$ variable (Discipline), which is 0.821 , is greater than the correlation value of the AVE dimension, which is 0.675. The AVE root value of the $Z$ variable (performance) is 0.808 , which is greater than the correlation value of the AVE dimension, which is 0.654 . The greater the AVE Root value, the tighter the dimensions in one variable.

\section{Composite Realibility}

"The next step is to know the reliability of a variable, the variable is said to be quite realistic if it has a construct reliability value greater than 0.6 . The value of construct reliability can be calculated using the Cronbach's Alpha (CA) and Composite Realibility (CR) methods ", Imam Ghozali (2015). As shown in table below.

Table 4. Cronbach's Alpha (CA) and Composite Realibility (CR)

\begin{tabular}{|l|c|c|}
\hline & $\begin{array}{c}\text { Cronbach's } \\
\text { Alpha }\end{array}$ & $\begin{array}{c}\text { Composite } \\
\text { Reliability }\end{array}$ \\
\hline WORK DISCIPLINE & $\mathbf{0 , 9 1 9}$ & $\mathbf{0 , 9 3 5}$ \\
\hline LEADERSHIP & $\mathbf{0 , 9 3 4}$ & $\mathbf{0 , 9 4 8}$ \\
\hline $\begin{array}{l}\text { EMPLOYEE } \\
\text { PERFORMANCE }\end{array}$ & 0,892 & 0,918 \\
\hline $\begin{array}{l}\text { ORGANIZATIONAL } \\
\text { COMMITMENT }\end{array}$ & 0,960 & 0,965 \\
\hline
\end{tabular}

Source: Output SmartPLS

From table 4 above shows that the data is realistic because the Cronbach's Alpha (CA) and Composite Realibility (CR) test values are above 0.6. According to Cooper et al. in Jogiyanto (2011) "a valid construct is definitely a realistic construct". From the results of the SmartPLS output, it can be concluded that the value of Cronbach's Alpha (CA) and Composite Realibility (CR) has met the reliability test because it has a value of $>0.6$, namely Leadership 0.934, Organizational Commitment 0.960, Work Discipline 0.919, and Employee Performance 0.892. Meanwhile, for Composite Realibility (CR), all variables have a value of $>0.6$, so it can be said that a construct is realistic or valid.

\section{Inner Model Testing \\ R Square}

"After the examination of the testing model is fulfilled, the next step is an examination of the structural model. This examination includes the significance of the path relationship and the value of R Square (R2) to see the results of the evaluation of the structural model, "Imam Ghozali (2015).

The value of $\mathrm{R}$ Square is to determine the influence of the independent variable on the dependent variable. Table 5 shows the value of R Square as follows: 
Table 5. R Square

\begin{tabular}{|l|c|c|}
\hline & R Square & R Square Adjusted \\
\hline WORK DISCIPLINE & $\mathbf{0 , 6 8 6}$ & $\mathbf{0 , 6 7 3}$ \\
\hline EMPLOYEE PERFORMANCE & $\mathbf{0 , 7 7 6}$ & $\mathbf{0 , 7 6 1}$ \\
\hline
\end{tabular}

Table 5 shows that the R Square value in the Work Discipline variable is 0.686 , meaning that in this study the variability of the Work Discipline construct can be explained by the variability of the Leadership and Organizational Commitment constructs of $68.6 \%$ and the remaining $31.4 \%$ by other variables outside the research model.

Employee Performance Variable is 0.776, meaning that in this study the variability of the Employee Performance construct can be explained by the variability of the Leadership construct, Organizational Commitment, and Work Discipline by $77.6 \%$ and the remaining $22.4 \%$ by other variables outside the research model.

The greater the value of R Square, the greater the influence of the independent variable to explain the independent variable and the better the structural equation.

\section{Effect Size (f square)}

The f square test is performed to determine the goodness of a model. f square is measured as the absolute value of the contribution of each variable.

According to Hair et.al in Masydzulhak et al (2016) "effect sizes are grouped into three categories: weak (0.02), moderate $(0.15)$, and strong $(0.35) "$.

\begin{tabular}{|l|c|c|}
\hline \multicolumn{1}{|c|}{ Table 6. Summary Results f square } \\
\hline & $\begin{array}{c}\text { WORK } \\
\text { DISCIPLIN } \\
\text { E }\end{array}$ & $\begin{array}{c}\text { EMPLOYEE } \\
\text { PERFORMANC } \\
\text { E }\end{array}$ \\
\hline $\begin{array}{l}\text { WORK } \\
\text { DISCIPLINE }\end{array}$ & & 0,162 \\
\hline LEADERSHIP & 0,109 & 0,059 \\
\hline $\begin{array}{l}\text { EMPLOYEE } \\
\text { PERFORMANCE }\end{array}$ & & \\
\hline $\begin{array}{l}\text { ORGANIZATIONA } \\
\text { L COMMITMENT }\end{array}$ & 0,506 & 0,242 \\
\hline \multicolumn{2}{|c|}{ Source: Output SmartPLS } \\
\hline
\end{tabular}

From table 6 it can be seen that the contribution of the Leadership variable to Work Discipline of 0.109 is included in the medium category, the Organizational Commitment variable to Work Discipline of 0.506 is included in the strong category, Leadership on Employee Performance of 0.059 is included in the weak category, Organizational Commitment to Employee Performance is 0.242 included in the medium category. Work Discipline on Employee Performance of 0.162 is included in the medium category.

\section{Q-Square}

"Goodness of fit assessment is known from the value of Q Square. The value of Q Square has the same meaning as coefficient determination ( $\mathrm{R}$ Square) in regression analysis. Where the higher the value of Q Square, the model can be said to be better or more fit with the data. 
The interpretation of GoF values is 0 - 0.25 (small GoF), 0.25 - 0.36 (medium GoF),> 0.36 (large GoF) ", Imam Ghozali (2015).

The Q Square value from the calculation results is as follows:

$$
\begin{aligned}
\text { Square } & =1-\left[\left(1-\mathrm{R}_{1}^{2}\right) \times\left(1-\mathrm{R}_{2}^{2}\right)\right] \\
& =1-\left[\left(1-0,686^{2}\right) \times\left(1-0,776^{2}\right)\right] \\
& =1-[(0,470) \times(0,398)] \\
& =1-0,1870 \\
& =0,813
\end{aligned}
$$

Based on the results of the above calculations, the Q Square value is 0.813 , meaning that the GoF model is in the large category and is able to explain the phenomenon. Thus, from these results, this research model can be stated as having a good goodness fit or it can be said that the model has a fairly good predictive value. In the end, the model can be used to test the hypothesis.

\section{Direct Effect}

To see the significance of the influence between the variables of Leadership, Work Discipline, Organizational Commitment, and the effect on Employee Performance, namely by looking at the original sample value and the $\mathrm{T}_{\text {Statistic }}$ significance value on each path.

\begin{tabular}{|c|c|c|c|c|c|}
\hline & $\begin{array}{c}\text { Origin } \\
\text { al } \\
\text { Sample } \\
(O)\end{array}$ & $\begin{array}{c}\text { Sampl } \\
\text { e } \\
\text { Mean } \\
(\mathbf{M})\end{array}$ & \begin{tabular}{|c} 
Standar \\
$\mathbf{d}$ \\
Deviatio \\
$\mathbf{n}$ \\
(STDEV \\
) \\
\end{tabular} & $\begin{array}{c}\text { TStatistics } \\
\text { (|O/STDE } \\
\text { V|) }\end{array}$ & $\begin{array}{c}\text { PValue } \\
\text { s }\end{array}$ \\
\hline WORK DISCIPLINE -> EMPLOYEE PERFORMANCE & $\mathbf{0 , 3 4 0}$ & $\mathbf{0 , 3 4 5}$ & $\mathbf{0 , 1 1 9}$ & 2,856 & 0,004 \\
\hline LEADERSHIP $->$ WORK DISCIPLINE & $\mathbf{0 , 2 7 9}$ & $\mathbf{0 , 2 8 6}$ & 0,149 & 1,871 & 0,062 \\
\hline LEADERSHIP -> EMPLOYEE PERFORMANCE & $\mathbf{0 , 1 8 2}$ & $\mathbf{0 , 1 6 4}$ & $\mathbf{0 , 1 2 4}$ & 1,461 & 0,145 \\
\hline $\begin{array}{l}\text { ORGANIZATIONAL COMMITMENT }->\text { WORK } \\
\text { DISCIPLINE }\end{array}$ & 0,599 & $\mathbf{0 , 5 9 0}$ & $\mathbf{0 , 1 3 3}$ & 4,509 & 0,000 \\
\hline $\begin{array}{l}\text { ORGANIZATIONAL COMMITMENT }>\text { EMPLOYEE } \\
\text { PERFORMANCE }\end{array}$ & $\mathbf{0 , 4 3 0}$ & 0,441 & 0,151 & 2,851 & 0,005 \\
\hline
\end{tabular}

SmartPLS output results using calculate-PLS Boostrapping with a test type One Tailed type and with a Significance level of 0.05. After the calculation, SmartPLS results data will appear which is then exported to Excel and the display is as follows:

Table 7. Path Coefficient

Based on table 7 the Path Coefficient output above shows the significance of the effect of the independent variable on the dependent variable:

1. The original sample value for the Leadership variable on the Work Discipline variable is 0.279 with a $\mathrm{T}_{\text {Statistic }}$ value of $1.871<1.967$ and $\mathrm{P}_{\text {Values }}$ at $0.062>0.05$, which means there is no influence.

2. The original sample value for the Organizational Commitment variable to the Work Discipline variable is 0.599 with a $\mathrm{T}_{\text {Statistic }}$ value of $4.509>1.967$ and $\mathrm{P}_{\text {Values }}$ of $0.000<$ $0.05)$ which means that there is a significant positive effect. 
3. The original sample value for the Leadership variable on the Employee Performance variable is 0.182 with a $\mathrm{T}_{\text {Statistic }}$ value of $1.461<1.967$ and $\mathrm{P}_{\text {Values }}$ of $0.145>0.05$, which means there is no influence.

4. The original sample value for the Organizational Commitment variable on the Employee Performance variable is 0.430 with a $\mathrm{T}_{\text {Statistic }}$ value of 2.851> 1.967 and $\mathrm{P}_{\text {Values }}$ of $0.005<$ 0.05 , which means that there is a significant positive effect.

5. The original sample value for the Work Discipline variable on the Employee Performance variable is 0.340 with a $\mathrm{T}_{\text {Statistic }}$ value of $2.856>1.967$ and $\mathrm{P}_{\text {Values }}$ of $0.005<0.05$ ) which means that there is a significant positive effect.

\section{Indirect Influence}

Based on table 8 the output of the Specific Indirect Effect can be explained as follows:

1. The value of the value of the indirect effect of leadership on employee performance through work discipline is $0.215>0.05$, which means that there is no indirect effect.

2. The value of the value of the indirect effect of Organizational Commitment on the Employee Performance variable through Work Discipline is $0.004<0.05$, which means that there is an indirect effect.

Table 8. Specifict Indirect Effect

\begin{tabular}{|c|c|c|c|c|c|}
\hline & $\begin{array}{c}\text { Original } \\
\text { Sample }(\mathbf{O})\end{array}$ & $\begin{array}{c}\text { Sample } \\
\text { Mean }(M)\end{array}$ & $\begin{array}{l}\text { Standard } \\
\text { Deviation } \\
\text { (STDEV) }\end{array}$ & $\begin{array}{c}\text { T}_{\text {Statistics }} \\
(|\mathrm{O} / \mathrm{STDEV}|)\end{array}$ & $\mathbf{P}_{\text {Values }}$ \\
\hline $\begin{array}{l}\text { LEADERSHIP -> WORK DISCIPLINE } \\
\text {-> EMPLOYEE PERFORMANCE }\end{array}$ & 0,095 & 0,106 & 0,076 & 1,242 & 0,215 \\
\hline $\begin{array}{l}\text { ORGANIZATIONAL COMMITMENT -> } \\
\text { WORK DISCIPLINE -> EMPLOYEE } \\
\text { PERFORMANCE }\end{array}$ & 0,204 & 0,198 & $\mathbf{0 , 0 7 0}$ & 2,907 & 0,004 \\
\hline
\end{tabular}

Source: Output SmartPLS

\section{Hypothesis Testing}

At the Path Coefficient output, as shown in table 7, we can see the significance of the effect of the independent variable on the dependent variable respectively.

The value of the original sample for the Leadership variable on the Work Discipline variable was 0.279 with a $\mathrm{T}_{\text {Statistic }}$ value of $1.871<1.967$ and $\mathrm{P}_{\text {Values }}$ at $0.062>0.05$, which means there is no influence.

The magnitude of the original sample value for the Organizational Commitment variable to the Work Discipline variable is 0.599 with a $\mathrm{T}_{\text {Statistic }}$ value of $4.509>1.967$ and $\mathrm{P}_{\text {Values }}$ of $0.000<0.05$, which means that there is a significant positive effect. The value of 0.599 means that the better and higher the organizational commitment, the better and high work discipline.

The magnitude of the original sample value for the Leadership variable on the Employee Performance variable is 0.182 with a $\mathrm{T}_{\text {Statistic }}$ value of $1.461<1.967$ and $\mathrm{P}_{\text {Values }}$ of $0.145>0.05$, which means there is no significant positive effect. 
The magnitude of the original sample value for the Organizational Commitment variable on the Employee Performance variable is 0.430 with a $\mathrm{T}_{\text {Statistic }}$ value of $2.851>1.967$ and $\mathrm{P}_{\text {Values }}$ of $0.005<0.05$, which means that there is a significant positive effect. The value of 0.430 in the original sample means that the higher the organizational commitment, the higher the employee's performance.

The magnitude of the original sample value for the Work Discipline variable on the Employee Performance variable is 0.340 with a $\mathrm{T}_{\text {Statistic }}$ value of $2.856>1.967$ and $\mathrm{P}_{\text {Values }}$ of $0.005<0.05$, which means that there is a significant positive effect. The value of 0.340 in the original sample means that the higher the work discipline, the higher the employee's performance.

It is known that the value of the Value of the Leadership variable is $0.215>0.05$, so it can be said that the leadership variable does not have an indirect influence on employee performance through work discipline.

It is known that the value of the value of the Organizational Commitment variable is 0.004 $<0.05$, it can be said that the Organizational Commitment variable has an indirect effect on Employee Performance through work discipline.

\section{Correlation Matrix}

"The results of SmartPLS output with Bootstrapping calculations show the Original Coefficient, $\mathrm{T}_{\text {Statistic }}$ values, and $\mathrm{P}_{\text {Values }}$ of each dimension with their indicators", Imam Ghozali (2015).

Table 9. Correlation Matrix Between Dimensions/Indicators

\begin{tabular}{|c|c|c|c|c|}
\hline & WORK DISCIPLINE & LEADER-SHIP & $\begin{array}{c}\text { EMPLOYEE } \\
\text { PERFOR-MANCE }\end{array}$ & $\begin{array}{l}\text { ORGANIZA-TIONAL } \\
\text { COMMIT-MENT } \\
\end{array}$ \\
\hline D1.1 & $\mathbf{0 , 8 3 2}$ & 0,504 & 0,668 & 0,660 \\
\hline D1.2 & $\mathbf{0 , 8 7 5}$ & $\mathbf{0 , 5 3 9}$ & 0,727 & 0,741 \\
\hline D2.1 & 0,900 & 0,604 & $\mathbf{0 , 7 2 3}$ & 0,779 \\
\hline D2.2 & $\mathbf{0 , 8 2 7}$ & 0,673 & 0,692 & 0,641 \\
\hline D3.1 & 0,791 & 0,666 & 0,610 & $\mathbf{0 , 5 5 2}$ \\
\hline D3.2 & $\mathbf{0 , 8 0 6}$ & 0,674 & 0,631 & $\mathbf{0 , 5 9 6}$ \\
\hline D4.3 & 0,706 & 0,526 & 0,647 & 0,649 \\
\hline K1.1 & 0,685 & 0,906 & 0,724 & 0,762 \\
\hline K1.2 & 0,650 & $\mathbf{0 , 8 6 0}$ & 0,658 & 0,652 \\
\hline K1.3 & $\mathbf{0 , 5 8 1}$ & $\mathbf{0 , 8 0 0}$ & 0,652 & 0,628 \\
\hline K1.4 & $\mathbf{0 , 5 9 2}$ & $\mathbf{0 , 8 8 2}$ & $\mathbf{0 , 5 9 8}$ & $\mathbf{0 , 5 9 5}$ \\
\hline K1.5 & 0,630 & 0,866 & 0,605 & $\mathbf{0 , 5 8 1}$ \\
\hline K1.6 & 0,635 & $\mathbf{0 , 8 9 1}$ & 0,657 & 0,655 \\
\hline KK1.1 & 0,561 & 0,435 & 0,726 & $\mathbf{0 , 5 5 3}$ \\
\hline KK1.2 & 0,646 & $\mathbf{0 , 5 2 0}$ & $\mathbf{0 , 8 5 0}$ & 0,632 \\
\hline KK1.3 & 0,639 & 0,513 & $\mathbf{0 , 8 3 5}$ & 0,599 \\
\hline KK2.1 & 0,704 & 0,710 & $\mathbf{0 , 8 8 1}$ & 0,790 \\
\hline KK2.2 & $\mathbf{0 , 7 3 8}$ & 0,714 & 0,862 & 0,826 \\
\hline KK3.2 & 0,656 & 0,679 & 0,677 & 0,609 \\
\hline KO1.1 & 0,749 & 0,744 & 0,691 & 0,861 \\
\hline KO1.2 & 0,768 & 0,751 & 0,742 & 0,912 \\
\hline K01.3 & 0,743 & 0,711 & 0,676 & 0,856 \\
\hline KO2.1 & 0,678 & 0,600 & 0,772 & $\mathbf{0 , 8 9 1}$ \\
\hline
\end{tabular}




\begin{tabular}{|l|l|l|l|l|}
\hline KO2.2 & $\mathbf{0 , 5 9 4}$ & $\mathbf{0 , 5 6 3}$ & $\mathbf{0 , 7 2 6}$ & $\mathbf{0 , 8 6 9}$ \\
\hline KO2.3 & $\mathbf{0 , 6 5 7}$ & $\mathbf{0 , 6 2 7}$ & $\mathbf{0 , 8 2 1}$ & $\mathbf{0 , 8 9 0}$ \\
\hline KO3.1 & $\mathbf{0 , 6 8 9}$ & $\mathbf{0 , 5 7 7}$ & $\mathbf{0 , 7 2 4}$ & $\mathbf{0 , 8 4 3}$ \\
\hline KO3.2 & $\mathbf{0 , 7 3 2}$ & $\mathbf{0 , 6 2 0}$ & $\mathbf{0 , 6 9 2}$ & $\mathbf{0 , 8 4 3}$ \\
\hline KO3.3 & $\mathbf{0 , 6 9 9}$ & $\mathbf{0 , 6 4 4}$ & $\mathbf{0 , 7 2 8}$ & $\mathbf{0 , 8 6 0}$ \\
\hline
\end{tabular}

Based on table 9 above, it shows that all dimensions in the research variables are significant in forming the construct. Meanwhile, to find out which dimension has the most influence on the construct or which dimension has the greatest contribution in shaping or influencing the construct, it can be seen from the value of the Loading Factor which has the largest contribution as well.

From this table it can also be shown that for the construct of Organizational Commitment the dimensions of KO1.2 (Identification) are 0.912. For the Employee Performance construct, the dimension that has the largest contribution is the KK2.1 dimension (encouragement and guidance) of 0.881 . For the construct of Work Discipline the dimension that has the largest contribution is the dimension D2.1 (a sense of belonging) of 0.900. For the Leadership construct, the dimension that has the largest contribution is the K1.1 dimension (Instruction) of 0.906 .

\section{Discussion}

\section{The Effect of Leadership on Work Discipline}

The magnitude of the original sample value for the leadership variable on work discipline is greater than the value of the T-statistic, and the value of the value is greater than the significance, which means that there is no influence between the leadership variable on work discipline. In other words, if leadership is improved or increased, it does not necessarily increase work discipline. Vice versa, if leadership decreases, it does not automatically reduce work discipline ..

\section{The Effect of Commitment on Work Discipline}

The magnitude of the original sample value for the variable organizational commitment to work discipline is greater than the T-statistic value, and the value of the value is smaller than the significance, which means that there is a positive and significant influence on the variable organizational commitment to work discipline. The value in the original sample means that the better and the higher the organizational commitment, the better and more disciplined.

\section{The Effect of Leadership on Employee Performance}

The size of the original sample value for the leadership variable on employee performance is greater than the $\mathrm{T}_{\text {Statistic }}$ value, and the value of the value is greater than the significance, which means that there is no influence of the leadership variable on employee performance. This means that if leadership increases, employee performance will not increase and vice versa, if leadership decreases, employee performance will also not decrease. 


\section{The Effect of Commitment on Employee Performance}

The magnitude of the original sample value for the variable organizational commitment to employee performance is greater than the value of $\mathrm{T}_{\text {Statistic }}$ and $\mathrm{P}_{\text {Values }}$ smaller than significance, which means that there is a positive and significant influence on the variable organizational commitment on employee performance. The value in the original sample means that the higher the organizational commitment, the higher the employee's performance.

\section{The Effect of Work Discipline on Employee Performance}

The magnitude of the original sample value for the work discipline variable on employee performance is greater than the $\mathrm{T}_{\text {Statistic }}$ and $\mathrm{P}_{\text {Values }}$ value is smaller than the significance, which means that there is a positive and significant influence of the work discipline variable on employee performance. The value in the original sample means that the higher the work discipline, the higher the employee's performance.

\section{Indirect Effect of Leadership on Employee Performance Through Work Discipline}

Based on the $\mathrm{P}_{\text {Values }}$ value generated in the Specific Indirect Effect table, the leadership variable has a value greater than the significance value. So it can be concluded that leadership does not have an indirect influence on employee performance through work discipline. Thus it can be said that work discipline does not mediate leadership on employee performance. This means that this indirect path equation cannot be used to predict changes in performance without changing leadership through work discipline. Work discipline variable is not needed to strengthen the influence of leadership on performance.

\section{Indirect Effect of Organizational Commitment on Employee Performance Through Work Discipline}

Based on the $\mathrm{P}_{\text {Values }}$ value generated in the Specific Indirect Effect table, the Organizational Commitment variable has a value smaller than the significance value. So it can be concluded that Organizational Commitment has an indirect effect on Employee Performance through Work Discipline. Thus it can be said that work discipline partially mediates organizational commitment to employee performance. This means that this indirect path equation can be used to predict changes in performance by changing organizational commitment through work discipline. Work discipline variable as an intervening variable that mediates partly (partial mediation) actually strengthens the effect of organizational commitment on performance.

\section{CONCLUSION}

\section{Conclusion}

Based on the results of research and discussion in the previous chapter, conclusions can be drawn about "The Effect of Leadership and Organizational Commitment on Employee Performance through Work Discipline as an Intervening Variable" as follows:

1. Leadership has no influence on Work Discipline. The instruction dimension has the greatest contribution to the leadership variable. This shows that Work Discipline will not increase if the boss provides instructions that match the needs of employees at work. 
2. Organizational Commitment has a significant influence on Work Discipline. The identification dimension has the greatest contribution to the Organizational Commitment variable. This shows that Work Discipline will increase if employees have a good identification of their future in the company.

3. Leadership has no effect on employee performance. The dimension of instruction on the performance of its subordinates has the greatest contribution to the leadership variable. This shows that employee performance will not increase if superiors provide precise and directed instructions according to the job needs of their subordinates.

4. Organizational Commitment has a significant influence on Employee Performance. The identification dimension of encouragement and guidance has the largest contribution to the Organizational Commitment variable. This shows that employee performance will increase if employees can identify the encouragement and guidance they receive to improve their performance at the company.

5. Work Discipline has a significant influence on Employee Performance. The dimension of a good sense of belonging has a great contribution to the Work Discipline variable. This shows that employee performance will increase if employees in the company have a good sense of belonging at work.

6. Leadership does not have an indirect influence on Employee Performance through Work Discipline. This is because work discipline is not a variable that mediates leadership on employee performance. This shows that if Leadership and Work Discipline are improved, the Employee Performance will not increase and vice versa if the Leadership and Work Discipline decreases, the Employee Performance will also not decrease.

7. Organizational Commitment has an indirect effect on employee performance through work discipline. This is because work discipline partially or partially mediates the influence of organizational commitment on employee performance. Where this shows that Employee Performance will increase if Organizational Commitment and Work Discipline are also increased because Work Discipline mediates some of its influence on Organizational Commitment in influencing Employee Performance.

\section{Suggestions}

Based on the research results obtained, the suggestions that can be conveyed are as follows:

1. Companies are advised to increase superiors' instructions for the performance of their subordinates, because if the company increases the superior's instructions for the performance of their subordinates, the values of leadership and employee performance will also increase.

2. Companies are advised to increase the identification of subordinates in every work activity, because if the identification of subordinates increases in each work activity, the values of leadership and employee performance will increase.

3. Companies are advised to increase superiors' instructions as a provider of encouragement and guidance for the problems of their subordinates, because if the company increases the instructions of superiors as a provider of encouragement and guidance for the problems of their subordinates, the values of leadership and employee performance will also increase. 
4. Companies are advised to increase the sense of pride of their employees being part of the company, because if the company increases the sense of pride in being part of the company, the organizational commitment and employee performance will also increase.

5. Companies are advised to increase identification of skills and knowledge, because if the company increases identification of skills and knowledge, organizational commitment and employee performance will also increase.

6. Companies are advised to improve Leadership with Work Discipline and Organizational Commitment with Work Discipline. Because if the company improves Leadership, Organizational Commitment, and Work Discipline, Employee Performance in the company will also increase.

7. Further researchers are advised to increase the number of population and add other variables such as job satisfaction, organizational culture, competence, and compensation and benefits.

\section{BIBLIOGRAPHY}

Abdul Raziq, Maqsood Ahmed 2014. The Influence of Career Commitment on Organizational Commitment among Selected Bankers in Lagos Metropolis, Nigeria, An Assessment of Organizational Commitment, HEC Recognized Journal, Vol.8, No. 1, pp: 1-110.

Alamsyah Muazzan , Seno Andri 2016. Pengaruh Pengembangan Karier Dan Komitmen Organisasi Terhadap Kinerja Karyawan Pada Pt. Indah Logistik Cargo Pekanbaru, Jom FISIP Vol 3 No. 2.

Arogundade Odunayo, T. (2014) The Influence of Career Commitment on Organizational Commitment among Selected Bankers in Lagos Metropolis, Nigeria. European Journal of Business and Management Vol.6, No.39, 2014.

As'ad, Mochammad. 2004. Psikologi Industri: Seri Sumber Daya Manusia. Yogyakarta. Liberty.

Boone \& Kurtz. (1984). Business. New York: Prenctice Hall.

Contessa, Zarah Winowod 2019. Pengaruh Motivasi Kerja, Disiplin Kerja Dan Komitmen Organisasi Terhadap Kinerja Karyawan SD Kristen Petra, Scholars Middle East Publishers, Dubai, United Arab Emirates, 5(8): 435-438.

Cooper dan Schindler. 2001. Metode Penelitian Survey. Edisi Bahasa Indonesia. Rineka Cipta. Jakarta.

Ega Syafiqi, Parwoto 2020. Pengaruh Disiplin Dan Motivasi Kerja Terhadap Kinerja Karyawan Bagian Lapangan. Jurnal Manajemen Pendidikan Islam, Jilid 5, Terbitan 2, Halaman 227-246,

Fomenky, Nkafu Fondu 2015. The Impact Of Motivation On Employee Performance. GlobalConference On Business and Finance Proceddings, Global Conference On Businnes And Finance Proceedings, Vol 10 No 1.

Garingging, R., et al. (2020). Influence of Leadership, Organizational Culture, and Millennial Employee Performance Compensation (Case Study in PT. XYZ Company).

Irejournals.Com, 4(1), 75-89. https://www.irejournals.com/formatedpaper/1702425.pdf

Gustiah, I. P., et al. (2018). The Influence of Transformational Leadership Style, Work

Motivation, and Organizational Culture on Employee Performance. Scholars Journal of 
Economics, Business and Management (SJEBM), 5(3), 1-12.

https://doi.org/10.21276/sjebm.2018.5.7.16

Handoko, T. Hani dan Sukanto. 2001. Organisasi Perusahaan, Teori, Struktur dan Perilaku.

Edisi 2 Yogyakarta. BPFE UGM.

Hasibuan, Malayu SP. 2006. Organisasi dan Motivasi. Jakarta. Bumi Aksara.

Hung-Jen Lo, Ph.D. Chun-Hung Lin, Prof. Dr. Lin Tung-Hsing Peng-Fei Tu 2014. The

Mediator Effect of Career Development Between Personality Traits and Organizational

Commitment: The Example of Sport Communication Technology Talents, Online Journal of Educational Technology, volume 13 issue 4.

Irdaningsih, H., Parwoto, \& Saluy, A. B. (2020). Influence of Leadership, Compensation \&

Commitment to Employee Performance In Pasar Mobil Kemayoran Management

(PPMK). Dinasti Internastional Journal of Education Management and Social Science,

1(3), 455-468. https://doi.org/10.31933/DIJEMSS

Iqbal Saba , Sadia Ehsan, Muhammad Rizwan, Mehwish Noreen 2014. The impact of organizational commitment, job satisfaction, job stress and leadership support on turnover intention in educational institutes, International Journal of Human Resource Studies, Vol.

4, No. 2.

Kemalasari, N., et al. (2018). The Effect of Human Capital, Structural Capital and Relation

Capital on Company Performance. Saudi Journal of Humanities and Social Sciences

(SJHSS), 6256. https://doi.org/10.21276/sjhss.2018.3.5.9

Kouzes M., James. \& Posner Z. Barry. (2004). Credibility (Translation) Professional Books. Jakarta.

Lashari Maryam , Amani Moazzam, Yaamina Salman, Sidra Irfan 2016. Impact of Organizational Trust On Organizational Justice And Organizational Commitment: A Case of University of Sargodha, JRSP Vol. 53, No. 2.

Luthan. 2006. Perilaku Organisasi. Jakarta. PT Indeks.

Mangkunegara, Anwar Prabu Waris, Abdul 2015. Effect of Training, Competence and Discipline on Employee Performance in Company (Case Study in PT Asuransi Bangun Askrida), Procedia - Social and Behavioral Sciences, 211 Pages 1240 - 1251.

Mangkunegara. 2007. Manajemen Sumber Daya Manusia. Bandung. PT Remaja Rosda Karya. Maria Riana Goretti Havidz Aima 2015. Pengaruh Budaya Kerja, Disiplin Kerja Terhadap Motivasi Kerja dan Implikasinya terhadap Kinerja karyawan PT. BNI (Persero) Tbk Cabang Bekasi, BUDAYA KERJA; MOTIVASI, Universitas Mercu Buana Press.

Mas'ud. 2004. Survei Diagnosis Organisasional: Konsep dan Aplikasi. Badan Penerbit Universitas Dipenegoro. Semarang.

Masydzulhak, Hapzi, dan Anggraeni LD, (2016). The Influence of work Motivation and Job Satisfaction on Employee Performance and Organizational Commitment Satisfaction as an Intervening Variable in PT Asian Isuzu Casting Center. Quest Journals, Journal of Research in Business and Management Volume 4 Issue 10(2016) pp: 01-10.

Mulyanto. 2009. Pengaruh Motivasi, Kepuasan Kerja Dan Komitmen Organisasi Terhadap

Kinerja Pegawai Pada Dinas Tenaga Kerja Dan Transmigrasi Provinsi Daerah Istimewa Yogjakarta. Jurnal Excellent Vol. 1 No. 2 September 2009, 123-144.

Musanti, T., et al. (2019). Pengaruh Pelatihan, Motivasi Kerja Dan Kompetensi Terhadap 
Kinerja Personel Di Makosek Hanudnas I. Journal of Management and Business

Review, 16(1), 87-109. https://doi.org/10.34149/jmbr.v16i1.151

Nduka, Obiekwe. 2016. Employee Motivation And Performance. Journal Of Centria University Of Applied Sciences Business Management.

Nuryanto, U. W., et al. (2020). Keunggulan Bersaing dalam Meningkatkan Kinerja Organiasi

Berkelanjutan. Jurnal Ilmu Manajemen Dan Bisnis Islam, 6(1), 1-22.

Pramudena, S. M., et al. (2020). The Effect of Intellectual Capital With The Components of

Human Capital and Satisfication on The Companies'Performance in .... Journal of

Critical ..., 7(19), 10118-10126. http://www.jcreview.com/?mno=26083

Priyono, Marzuki, Soesatyo. 2016. Influence Of Motivation And Discipline On The Performance Of Employees (Studies On, CV Eastern Star Home In Surabaya). Journal Of Global Economics, Management And Business Research, Vol 5 No.3 hal 212-220.

Rivai. 2005. Manajemen Sumber Daya Manusia untuk Perusahaan, dari Teori ke Praktek. Jakarta. Murai Persada Divisi Buku Pilihan PT Raja Grafindo Persada.

Rismawati., (2018)., Pengaruh Gaya Kepemimpinan Transformasional, Disiplin Kerja Dan Kompensasi Terhadap Kinerja Guru SMK Global Mulia Bekasi,. AMAR (Andalas Management Review), Volume 2 Issue 2 Pages 42-58.

Robbins, P. Stephen (2006). Organizational Theory: Structure, Design, and Applications. Interpreting: Yusuf Udaya. Jakarta: Arcan.

Robbins, P. Stephen \& Coulter Mary. (2010). Management (Tenth Edition). Jakarta: Erland.

Robbins, P. Stephen. 2006. Perilaku Organisasi. Edisi Lengkap Bahasa Indonesia Jakarta. PT Indeks, Kelompok Gramedia.

Robert, C Probst. 2000. Empowerment and Continuous Improvement in The United States, Mexico, Poland and India: Predicting Fit on The Basis of The Dimensions of Power Distance and Individualism. Journal of Applied Psychology. 85 (5), 643-658.

Rotter, J.B. (1990), Internal versus eksternal control of reinforcement. American Psychologist, Vol. 45 No. 4, pp. 489-93.

Salutondok Yohanis Agus Supandi Soegoto 2015. Pengaruh kepemimpinan, motivasi, kondisi kerja dan disiplin terhadap kinerja pegawai di kantor sekretariat DPRD Kota Sorong, JURNAL RISET EKONOMI, MANAJE-MEN, BISNIS DAN AKUNTANSI, Vol. 3, No. 3.

Saluy,AB., Pengaruh Pelatihan, Motivasi Kerja Dan Kompetensi Terhadap Kinerja Personel Di Makosek Hanudnas, Tersia Musanti 2018. Journal of management and business review PPM Jakarta, Volume 2 Issue 2 PPM 151.

Prawira, B., et al. The Influence of Leadership, Working Culture, and Working Environment for the Ministry of Administrative Reform and Bureaucracy. IJBEA: http:// creativecommons.org/licenses/by-nc/4.0

Santoso, Joko (2014). "Pengaruh Kepemimpinan Terhadap Kinerja Pegawai Dengan Disiplin Kerja Sebagai Variabel Intervening (pada Kantor Wilayah Kementerian Agama Provinsi Kalimantan Tengah)". Masters thesis, Universitas Terbuka

Shadur, Kinzle dan Rodwell. 1999. The Contribution of Total Anality Management to a Theory of Work kinerja, Academy of Management Review, Vol 19 No.3, pp 210-536. 
Shelviana Sherly 2016. Hubungan Disiplin Kerja dengan Kinerja Pegawai Negeri Sipil (PNS) di Kecamatan Samarinda Ulu Kota Samarinda, eJournal Ilmu Administrasi Negara, Vol. 3, No. 4.

Simamora, Henry.1997. Manajemen sumber daya manusia. Edisi Kedua. Yogyakarta: STIE YKPN.

Sinem Aydogdu, Baris Asikgil 2011. An Empirical Study of the Relationship Among Job Satisfaction, Organizational Commitment and Turnover Intention, International Review of Management and Marketing Vol. 1, No. 3, 2011, pp.43-53.

Sukmawati Dally 2017. Pengaruh Motivasi, Disiplin dan Kompetensi Terhadap Kinerja Pegawai, Jurnal Publik, Vol. 11, No. 02, hal 269-278.

Suzulia, M. T., \& Saluy, A. B. (2020). The Effect of Capital Structure, Company Growth, and Inflation on Firm Value With Profitability as Intervening Variable (Study on Manufacturing Companies Listed on Bei Period 2014-2018). Dinasti International Journal of Economics, Finance \& Accounting, 1 (1), 95-109.

Titik Nurbiyati, Kunto Wibisono (2014). “Analisis Pengaruh Komitmen Afektif, Kontinyu, dan Normatif Terhadap Kinerja Dengan Disiplin Kerja Sebagai Variabel Intervening”. JURNAL KAJIAN BISNIS VOL. 22, NO.1, 2014, 21-37.

Tranggono, RP dan Kartika, Andi. (2008). Pengaruh Komitmen Organisasional Dan Profesional Terhadap Kepuasan Kerja Auditor Dengan Motivasi Sebagai Variabel Intervening. Jurnal Bisnis dan Ekonomi (JBE), Maret 2008, Hal. 80-90 Vol. 15, No.1.

Treshia, Y., et al. (2018). Pengaruh Motivasi Kerja, Disiplin Kerja dan Kompensasi Terhadap Kinerja Karyawan(Studi Kasus di Perusahaan PT IE). Jurnal Ilmiah Manajemen Dan Bisnis, 02(January), 50-70.

Triraharjo, J., et al.(2020). Effect of Transformational Leadership and Breakthrough Leadership on Organizational Performance through the Variable of Employee Satisfaction: A Case Study. International Journal of Economics and Business Administration, VIII(Issue 3), 554-568. https://doi.org/10.35808/ijeba/554

Utari \& Suyatmin (2015). "Pengaruh Motivasi, Keoemimpinan, dan Kedisiplinan Terhadap Kinerja Pegawai (Studi Kasus Pada Dinas Pendapatan, Pengelolaan Keuangan dan Aset Daerah Wonogiri)" Skripsi thesis, Universitas Muhammadiyah Surakarta.

Wibowo Susilo YB, Noviantoro C; Suprijandoko F; Wahyono T, Hakim LN, Astawa IMMK, Kasma VS, Nusaputra S, Hasditama MA. (2015). Peranan Persandian Dalam Mengawal Nawa Cita, Bagian Humas dan Kerjasama Lemsaneg.

Wright dan Bonett. 2002. Organization Behavior an Introductory Text. Europe. Prentice Hall. 